\title{
Ability of dairy cows to ensure pregnancy according to breed and genetic merit for production traits under contrasted pasture-based systems
}

\author{
N. Bedere,${ }^{*}$ C. Disenhaus, ${ }^{* 1}$ V. Ducrocq, $\dagger$ S. Leurent-Colette, $\ddagger$ and L. Delaby* \\ *PEGASE, Agrocampus Ouest, INRA, 35590, Saint-Gilles, France \\ †GABI, INRA, AgroParisTech, Université Paris-Saclay, 78350, Jouy-en-Josas, France \\ ‡Domaine Expérimental du Pin-au-Haras, INRA, 61310, Exmes, France
}

\begin{abstract}
The present study aimed to assess and measure the effects of breed, genetic merit for production traits, and feeding systems (FS) on the ability of dairy cows to ensure pregnancy through its components (fertilization, embryonic losses, recalving). An experiment was conducted over 9 yr on Normande and Holstein cows assigned to contrasted FS. Diets were based on maize silage in winter and grazing plus concentrate in spring in the high FS group, and on grass silage in winter and grazing with no concentrate during spring in the low FS group. Within breeds, cows were classified into 2 groups with similar estimated breeding values (EBV) for milk solids: cows with high EBV for milk yield were included in a milk group and those with high EBV for fat and protein contents were included in a content group. Holstein cows produced more milk throughout lactation than Normande cows (the differential was greater in the high FS group, +2,294 kg, compared with $+1,280 \mathrm{~kg}$ in the low FS group) and lost more body condition to nadir (the differential was greater in the high FS group, -1.00 point, compared with -0.80 point in the low FS group). Within breeds, milk solids production was similar between genetic groups. Cows in the high FS group produced more milk $(+2,495 \mathrm{~kg}$ for Holstein and $+1,481 \mathrm{~kg}$ for Normande cows) and had a higher body condition score at nadir $(+0.40$ point for Holstein and +0.60 point for Normande) than cows in the low FS group. Holstein cows had a lower recalving rate than Normande cows ( -19 percentage units). We found no effect of genetic group and FS on fertility of Normande cows. However, according to FS, Holstein cows in the content group exhibited different fertility failure patterns. In the low FS group, Holstein cows in the content group had more nonfertilizations or early embryo mortality $(+26$ percentage units at first and second services) than Holstein cows in the milk group.
\end{abstract}

Received June 10, 2016.

Accepted December 12, 2016.

${ }^{1}$ Corresponding author: catherine.disenhaus@agrocampus-ouest.fr
In the high FS group, Holstein cows in the content group had a higher proportion of late embryo mortality than in the milk group $(+10$ percentage units at first and second services). We observed no effect of FS on recalving rate; however, indicators of energy balance (protein content or body condition score) were positively associated with successful conception and pregnancy. This suggested a link between genetic merit for fat and protein content and lower ability of dairy cows to ensure pregnancy because of more nonfertilizations and early or late embryo mortality.

Key words: dairy cow, genetic merit, fertilization, pregnancy loss

\section{INTRODUCTION}

In the past decades, reproductive performance of dairy cows has been declining and the strong genetic selection that was applied on production traits is considered to be responsible for this. Each step of the reproductive step has been affected: abnormal ovarian activity is more common in the current population (Gautam et al., 2010), the duration and intensity of estrus has markedly decreased (Kerbrat and Disenhaus, 2004), and the occurrence of pregnancy losses has increased (Grimard et al., 2006). The consensus in the literature is that fertility is impaired by a lack of energy because dairy cows are investing it in milk production, and that this competition is both genetically and nutritionally driven (Royal et al., 2000; Friggens et al., 2010; Walsh et al., 2011).

In various regions, the valuable milk components are fat and protein. Two possible ways exist to produce fat and protein, either through high milk yield or through high fat and protein contents. In the literature, most studies investigating the effect of genetics on production and reproduction performance compared either high and low genetic merit for milk yield (Kennedy et al., 2003; Horan et al., 2004), or high and low genetic merit for milk solids yield (Fulkerson et al., 2001; Pollott and Coffey, 2008). To our knowledge, a comparison of high genetic merit for milk yield and high genetic 
merit for fat and protein contents at identical global genetic merit for milk solids has never been investigated before. At identical milk solids yield, dairy cows with high genetic merit for fat and protein contents should have a lower peak milk yield and lower lactose yield than cows with high genetic merit for milk yield. Therefore, cows with high genetic merit for fat and protein contents are expected to invest less energy in milk than cows with high genetic merit for milk yield. It can be hypothesized that dairy cows with high genetic merit for fat and protein content preserve their reproductive performance while producing the same amount of milk solids than cows with high genetic merit for milk yield. A previous study showed that primiparous dairy cows with high genetic merit for fat and protein content had an earlier commencement of luteal activity than those with high genetic merit for milk yield in 2 contrasted breeds (dairy vs. dual-purpose cows) and 2 contrasted feeding systems (high vs. low inputs; Bedere et al., 2016a). This was a promising result to establish strategies to cope with reproductive decline and maintain productive performance. However, knowledge concerning the ability of this type of cows to ensure pregnancy is lacking. The present study aimed to assess and measure the effects of breed, genetic merit for production traits, and feeding systems on the fertility of dairy cows. Our hypotheses were that (1) high genetic merit for milk yield is unfavorably associated with the ability to ensure pregnancy, and (2) according to genetic characteristics, dairy cows under nutrient restriction are either preserving body reserves or milk production.

\section{MATERIALS AND METHODS}

\section{Experimental Design}

An experiment was conducted from 2006 to 2014 at the INRA dairy research farm of Le Pin-au-Haras (latitude 48.724986, longitude 0.185428; Normandy,
France). Dairy cows were equally distributed over 2 breeds and 2 feeding systems (FS) each experimental year. A total of 296 lactations from 132 Normande cows (dual-purpose cows) and 240 lactations from 128 Holstein cows (dairy cows) were recorded throughout the trial. Within breeds, cows were classified into 2 groups according to their EBV for milk yield or fat and protein contents, as these 2 groups are capable of producing the same milk solids quantity in different manners. Estimated breeding value for each trait were obtained by combining within herd information analyzed with a BLUP animal model with national EBV of the sires and grandsires. The model of analysis of cow performance over 3 lactations included usual fixed environmental effects (year, lactation number, calving age, calving month, drying off period length, and permanent environment effect) and the feeding system (H. Larroque, INRA UMR 1388 GenPhySE, Toulouse, France, personal communication). Within breed and experimental year, nulliparous cows with EBV for milk yield higher than average and EBV for fat and protein contents lower than average constituted a milk group. Nulliparous cows with EBV for milk yield lower than average and EBV for fat and protein contents higher than average constituted a content group. The other nulliparous cows (with high EBV for milk yield and high EBV for fat and protein contents or low EBV for milk yield and low EBV for fat and protein contents) did not enter the experiment (Table 1). There were 116 lactations from 56 Holstein cows and 147 lactations from 65 Normande cows recorded under a high FS that enabled high milk yield while limiting body condition loss; there were 124 lactations from 72 Holstein cows and 149 lactations from 67 Normande cows recorded under a low FS that limited milk yield while inducing a large body condition loss. Diets are presented in Table 2. Cows remained in their FS until they were culled due to infertility, severe health problem, or death. Among the 536 lactations recorded in this study, 15 were removed because the cows could not be milked and 21 were re-

Table 1. Estimated breeding values for production traits (milk yield, fat content, protein content, fat yield, protein yield, milk solids yield) for Holstein and Normande cows, in the milk or the content group

\begin{tabular}{lccccc}
\hline & \multicolumn{2}{c}{ Holstein } & & \multicolumn{2}{c}{ Normande } \\
\cline { 2 - 3 } \cline { 5 - 6 } Item $^{1}$ & Milk group & Content group & & Milk group & Content group \\
\hline EBV for milk yield $(\mathrm{kg})$ & +308 & -303 & & +290 & -264 \\
EBV for fat content $(\mathrm{g} / \mathrm{kg})$ & -1.7 & +1.9 & & -1.9 & +1.5 \\
EBV for protein content $(\mathrm{g} / \mathrm{kg})$ & -0.5 & +0.5 & & -0.9 & +0.8 \\
EBV for fat yield $(\mathrm{kg})$ & -1.8 & +1.1 & & +1.1 & -2.3 \\
EBV for protein yield $(\mathrm{kg})$ & +6.3 & -5.5 & & +4.7 & -4.4 \\
EBV for milk solids $(\mathrm{kg})$ & +4.4 & -4.4 & & +5.8 & -6.8 \\
\hline
\end{tabular}

${ }^{1}$ All EBV were expressed in deviation from a base population, whose average EBV were set to 0 . 
Table 2. Composition of the diets of the high and low feeding systems during stock, pasture, and dry periods

\begin{tabular}{|c|c|c|}
\hline Feedstuffs & $\begin{array}{l}\text { High } \\
\text { feeding } \\
\text { system }\end{array}$ & $\begin{array}{l}\text { Low } \\
\text { feeding } \\
\text { system }\end{array}$ \\
\hline \multicolumn{3}{|l|}{ Indoor diet (early lactation) } \\
\hline Maize silage (\% DM) & 55 & - \\
\hline Dehydrated alfalfa pellets (\% DM) & 15 & - \\
\hline Grass silage (\% DM) & - & 50 \\
\hline Haylage (\% DM) & - & 48 \\
\hline $\begin{array}{l}\text { Concentrates + minerals and vitamins } \\
(\% \mathrm{DM})\end{array}$ & 30 & - \\
\hline Minerals and vitamins (\% DM) & - & 2 \\
\hline \multicolumn{3}{|l|}{ Pasture feeding (mid and late lactation) } \\
\hline Rotational grazing (ha/cow) & $0.35^{1}$ & $0.55^{2}$ \\
\hline Concentrates $(\mathrm{kg})$ & 4.00 & - \\
\hline Minerals and vitamins $(\mathrm{kg})$ & 0.25 & 0.50 \\
\hline \multicolumn{3}{|l|}{ Dry period diet } \\
\hline Grass silage (\% DM) & 100 & 100 \\
\hline
\end{tabular}

${ }^{1}$ In the case of grass scarcity, cows received maize silage. This occurred often around mid July.

${ }^{2}$ In the case of grass scarcity, cows received grass silage. This occurred rarely during summer and late October.

moved because of severe health problems. Finally, 500 lactations, including 207 from first-lactation cows, were included in the analyses of the present study.

\section{Reproductive Management}

The herd was managed under a 3-mo compact calving system (January-March). After calving, uterine involution was checked by rectal palpation 25 to 30 d postpartum. When involution was achieved, AI were performed on spontaneous estrus if expressed at least $40 \mathrm{~d}$ postpartum and during the breeding period (April-June). If cows were not expressing new estrus in the $35 \mathrm{~d}$ following a service, ultrasonography was conducted to diagnose pregnancy status. If the first one was positive, a second diagnosis was performed $60 \mathrm{~d}$ after last service. Insemination outcomes were classified by combining information from progesterone (P4) profiles and ultrasonography examinations (Humblot, 2001; adapted by Cutullic et al., 2011; Table 3) as nonfertilization or early embryo mortality (NF/EEM), late embryo mortality (LEM), fetal death (FD), abortion, and calving.

Health events were recorded throughout the lactation with special care on reproductive problems (caesarian, vagina displacement, infectious vaginitis, severe metritis, and retained placenta). Anestrus was not considered to be a pathology, and cows that were not seen in estrus before the end of the breeding season were not treated to avoid introducing a bias in the analyses. During this experiment, 107 cows (21\%) experienced reproductive problems. Due to their potential effect on reproductive performance, the effect of having at least 1 of the reproductive problems described above was accounted for in the analyses as a dichotomous variable $(0=$ none, $1=$ at least one reproductive problem).

\section{Sampling and Measurements}

Cows were milked twice daily at 0630 and $1600 \mathrm{~h}$. Individual milk yields were recorded by flow meters (Metatron, Westfalia, Germany). Fat and protein contents from a.m. and p.m. individual milk samples were determined 3 times a week by infrared analyzer (MilkoScan, Foss Electric, Hillerød, Denmark). Morning milk samples were taken from calving to either $2 \mathrm{wk}$ after service inducing pregnancy or to the end of July on Monday, Wednesday, and Friday and stored at $-20^{\circ} \mathrm{C}$. Milk P4 concentration was determined using commercial ELISA kits (Milk Progesterone ELISA, Ridgeway Science Ltd., St. Briavels, Gloucestershire, UK). The coefficients of variation between assays on $5-\mathrm{ng} / \mathrm{mL}$ control samples ranged between 8 and 14\% among experimental years. Two milk P4 thresholds were defined to distinguish the baseline level of progesterone in milk from the luteal phase level (threshold 1) and a low luteal phase level from a high luteal phase level (threshold 2; Petersson et al., 2006; adapted by Cutullic et al., 2011). In short, threshold 1 was the $\mathrm{P} 4$ concentration below $95 \%$ of $\mathrm{P} 4$ values at observed estruses (Petersson et al., 2006). Threshold 2 corresponded to the first quartile value of the points above threshold 1 . Across experimental years, their values ranged from 0.01 to

Table 3. Decision rules to classify insemination outcomes by combining information from progesterone levels (luteal phase length) and ultrasonography examinations

\begin{tabular}{|c|c|c|c|}
\hline $\begin{array}{l}\text { Insemination } \\
\text { outcome }^{1}\end{array}$ & Luteal phase length (d) & Ultrasonography $^{2}$ & Other \\
\hline $\begin{array}{l}\text { NF/EEM } \\
\text { LEM } \\
\text { FD } \\
\text { Abortion } \\
\text { Calving }\end{array}$ & $\begin{array}{l}<25 \\
\geq 25 \text { and }<50 \\
\geq 50 \\
\geq 50 \\
\geq 50\end{array}$ & $\begin{array}{l}\text { E. or P. } 35 \mathrm{~d} \\
\text { P. } 35 \text { and E. } 70 \mathrm{~d} \\
\text { P. } 35 \text { and } 70 \mathrm{~d} \\
\text { P. } 35 \text { and } 70 \mathrm{~d}\end{array}$ & $\begin{array}{l}\text { (aborted fetus) } \\
\text { calf }\end{array}$ \\
\hline
\end{tabular}


$1.49 \mathrm{ng} / \mathrm{mL}$ for threshold 1 and from 2.03 to $6.37 \mathrm{ng} /$ $\mathrm{mL}$ for threshold 2. A luteal phase was considered to start when at least 2 consecutive milk $\mathrm{P} 4$ concentrations were above threshold 1 and at least 1 above threshold 2 ; the phase ended when at least 1 value was lower than threshold 1. Blood samples from the caudal vein were taken at 20 and $60 \mathrm{~d}$ postpartum to determine plasma concentrations of glucose, fatty acids, and urea using enzymatic colorimetry (Kone Instruments Corporation, Espoo, Finland). Body condition score ( $0-5$ scale with 0.25 increments) was evaluated monthly by the same 3 trained assessors as described by Bazin et al. (1984). Lactation persistency was defined as the ratio between average daily milk yield from 100 to 200 DIM and average daily milk yield over the first 100 DIM.

\section{Statistical Analyses}

In this section, all complete models are described. From these complete models, a backward selection was applied to keep only significant effects in the final models. Effects were kept in the final models if their $P$-value was lower than 0.10. In some cases, the estimation of variance components failed, probably because of a too limited number of records. In such cases, an empirical Bayesian approach was implemented. All Bayesian mixed models were performed using the blmer (linear mixed models) or bglmer (generalized linear mixed models) procedures of the $\mathrm{R}$ statistical package ( $\mathrm{R}$ Core Team, 2016).

Production Performance. Production performance were studied using the following initial linear mixed model

$$
\begin{gathered}
\mathrm{y}_{\mathrm{ijklmn}}=\mu+\beta_{1} \text { grazing }_{\mathrm{ijklmn}}+\beta_{2} \mathrm{EBV}_{\mathrm{ijklmn}} \\
+ \text { year }_{\mathrm{i}}+\text { parity }_{\mathrm{j}}+\text { breed }_{\mathrm{k}}+(\mathrm{GG} \mid \text { breed })_{\mathrm{kl}}+\mathrm{FS}_{\mathrm{m}} \\
+ \text { parity } \times \text { breed }_{\mathrm{jk}}+\text { parity } \times \mathrm{FS}_{\mathrm{jm}}+\text { breed } \times \mathrm{FS}_{\mathrm{km}} \\
+(\mathrm{GG} \mid \text { breed }) \times \mathrm{FS}_{\mathrm{klm}}+\text { cow }_{\mathrm{n}}+\mathrm{e}_{\mathrm{ijklmn}},
\end{gathered}
$$

where $y_{\mathrm{ijklmn}}$ was the production performance (e.g., milk yield over the first $14 \mathrm{wk}$ of lactation), $\mu$ was the mean

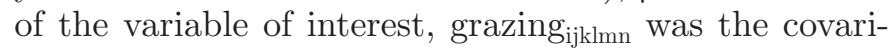
ate describing the effect of DIM at turnout, $\mathrm{EBV}_{\mathrm{ijklmn}}$ was the covariate describing the effect of the associated EBV centered within breeds and genetic groups (when the dependent variables were milk yield, fat and protein contents, or yields), year ${ }_{i}$ was the fixed effect of experimental year ( $\mathrm{i}=2006$ to 2014), parity $_{\mathrm{j}}$ was the fixed effect of parity $(\mathrm{j}=1,2$, or $\geq 3)$, breed $_{\mathrm{k}}$ was the fixed effect of breed ( $\mathrm{k}=$ Holstein or Normande cows), $(\mathrm{GG} \mid \text { breed })_{\mathrm{kl}}$ was the fixed effect of genetic group $(\mathrm{l}=$ milk group or content group) nested within breed, $\mathrm{FS}_{\mathrm{m}}$ was the fixed effect of feeding system $(\mathrm{m}=$ high or low), $\operatorname{cow}_{\mathrm{n}}$ was the random (genetic and non-genetic) effect of the cow, and $\mathrm{e}_{\mathrm{ijk} k \mathrm{mn}}$ was the random residual effect. All linear mixed model analyses were performed using the lmer procedure of the $\mathrm{R}$ statistical package (R Core Team, 2016).

Metabolites. Plasma concentrations of glucose, fatty acids, and urea were studied using the following initial linear mixed model

$$
\begin{gathered}
\text { y }_{\mathrm{ijklmno}}=\mu+\text { out }_{\mathrm{o}}+\text { year }_{\mathrm{i}}+\text { parity }_{\mathrm{j}}+\text { breed }_{\mathrm{k}} \\
+(\mathrm{GG} \mid \text { breed })_{\mathrm{kl}}+\mathrm{FS}_{\mathrm{m}}+\text { parity } \times \text { breed }_{\mathrm{jk}}+\text { parity } \\
\times \mathrm{FS}_{\mathrm{jm}}+\text { breed } \times \mathrm{FS}_{\mathrm{km}}+(\mathrm{GG} \mid \text { breed }) \\
\times \mathrm{FS}_{\mathrm{klm}}+\text { cow }_{\mathrm{n}}+\mathrm{e}_{\mathrm{ijklmno}},
\end{gathered}
$$

where $y_{\mathrm{ijklmno}}$ was the plasma concentration of interest (e.g., glucose $20 \mathrm{~d}$ postpartum). The independent variables were as described earlier, with the substitu-

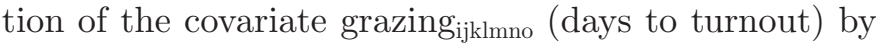
the fixed effect of the type of diet out $(\mathrm{o}=$ indoor or pasture diet) at the time of blood sampling.

Inseminations Outcomes. Inseminations outcomes were studied using the following initial generalized (logistic) linear mixed models

$$
\begin{aligned}
& \log \left[\frac{P\left(\mathrm{y}_{\mathrm{ijklmno}}=1\right)}{1-P\left(\mathrm{y}_{\mathrm{ijklmno}}=1\right)}\right]=\mu+\beta_{1} \text { grazing }_{\mathrm{ijklmno}}+\beta_{2} \operatorname{dim}_{\mathrm{ijklmno}} \\
& + \text { year }_{\mathrm{i}}+\text { parity }_{\mathrm{j}}+\text { breed }_{\mathrm{k}}+\left(\mathrm{GG} \mid \mathrm{breed}_{\mathrm{kl}}+\mathrm{FS}_{\mathrm{m}}+\mathrm{cpb}_{\mathrm{o}}\right. \\
& + \text { parity } \times \text { breed }_{\mathrm{jk}}+\text { parity } \times \mathrm{FS}_{\mathrm{jm}}+\text { breed } \times \mathrm{FS}_{\mathrm{km}} \\
& +(\mathrm{GG} \mid \text { breed }) \times \mathrm{FS}_{\mathrm{klm}}+\mathrm{cow}_{\mathrm{n}},
\end{aligned}
$$

where $y_{i j k l m n o}$ was the outcome of inseminations as dichotomous variables (NF/EEM: 0/1, LEM: 0/1, FD/ abortion: 0/1, calving: 0/1). The independent variables were as described earlier with the addition of the covariate $\beta_{2} \operatorname{dim}_{\mathrm{ijklmno}}$, describing the effect of DIM, and of $\mathrm{cpb}_{\mathrm{o}}$, describing the fixed effect of calving problems (o $=0$ or 1 ). All generalized linear mixed model analyses were performed using the glmer procedure of the $\mathrm{R}$ statistical package (R Core Team, 2016).

Days to Conception and Calving Service. The times from start of the breeding season (with additional required days: if a cow calved March 15, considering the voluntary waiting period of $40 \mathrm{~d}$, she was allowed to be inseminated April 24 even though the breeding period started April 1) to conception [days to AI resulting in fertilization of the oocyte (DAIF)] or to successful service [days to AI resulting in calving (DAIC)] were studied using survival techniques. Both DAIF and DAIC may be different because of LEM, FD, and 
abortions. A parametric proportional hazard model was used, assuming a Weibull baseline. The hazard for any animal t-days after possible service was modeled as follows:

$$
\mathrm{h}(\mathrm{t} ; \mathbf{x}, \mathbf{z})=\lambda \rho(\lambda \mathrm{t})^{\rho-1} \exp \left[\mathbf{x}^{\prime} \beta+\mathbf{z}^{\prime}(\mathrm{t}) \varphi\right]
$$

where $\lambda \rho(\lambda t)^{\rho-1}$ is a Weibull baseline hazard function using 2 parameters $(\lambda$ and $\rho), \mathbf{x}$ is an incidence vector relating the hazard function to a set of timeindependent effects $\beta$, including all variables described in the preceding model (with the addition of days from the start of the breeding season to first service to study DAI, and the effect of DAIF to study DAIC), and $\mathbf{z}$ is an incidence vector relating the hazard function to time-dependent effects $\varphi$, including protein content in the case of DAIF and milk yield for DAIC. By the end of the breeding season, if no AI resulting in either fertilization of the oocyte or calving was observed, the observation was censored. In such cases, DAIF and DAIC were computed as the time between the start of the breeding season (adjusted for the voluntary waiting period) and its end. Survival analyses make use of this partial information. The estimation of variance components failed, probably because of a too limited number of records. Animal variance was fixed at 0.49, assuming a log-gamma distribution for this effect (a common practice in frailty models) with parameter $\gamma$ equal to 0.4. The robustness of the models was tested by comparing the results with an animal variance equal to $0.22(\gamma=0.2)$ and $1.64(\gamma=0.8)$, and the other results were similar. All survival analyses were performed using the Survival Kit statistical package (Mészáros et al., 2013).

\section{RESULTS}

\section{Production Performance}

Effects of Genetic Merit for Milk Yield. Holstein cows produced more milk $(+2,294 \mathrm{~kg}$ in the high FS and $+1,280 \mathrm{~kg}$ in the low FS; $P<0.001$; Table 4) and more milk solids $(+120 \mathrm{~kg}$ in the high FS and $+62 \mathrm{~kg}$ in the low FS, $P<0.001)$ throughout lactation than Normande cows. Over the firsts 14 wk of lactation, Holstein cows had lower fat $(-1.0 \mathrm{~g} / \mathrm{kg} ; P<$ $0.01)$ and protein content $(-2.5 \mathrm{~g} / \mathrm{kg} ; P<0.001)$ than Normande cows. Holstein cows had a higher peak milk yield $(+12.0 \mathrm{~kg}$ in the high FS and $+6.3 \mathrm{~kg}$ in the low FS; $P<0.001)$ and a lower persistency $(-2$ percentage units; $P<0.05)$ than Normande cows. Holstein cows had a lower BCS at calving $(-0.70$ points in the high FS and -0.35 points in the low FS; $P<0.001$ ), at nadir $(-1.00$ points in the high FS and -0.80 points in the low FS; $P<0.001)$, and at the end of lactation $(-1.05$ points in the high FS and -0.75 points in the low FS; $P<0.001)$ than Normande cows. At $20 \mathrm{~d}$ postpartum, Holstein cows had a similar glycaemia $(P=0.55$; Table 5), higher plasma fatty acid concentration $(+128$ $\mu \mathrm{mol} / \mathrm{L} ; P<0.001)$ and a lower uremia $(-1.9 \mathrm{mg} / \mathrm{dL}$; $P<0.01)$ than Normande cows. At 60 d postpartum, Holstein cows had a higher glycaemia $(+1.6 \mathrm{mg} / \mathrm{dL} ; P$ $<0.01)$, higher plasma fatty acid concentration $(+28$ $\mu \mathrm{mol} / \mathrm{L} ; P<0.01)$, and similar uremia $(P=0.29)$ than Normande cows.

Milk solids production was similar between genetic groups within breeds $(+15 \mathrm{~kg}$ for cows in the milk compared with content group within breeds; $P=0.17$ and 0.12 for Holstein and Normande cows, respectively) and we found no interaction with FS $(P=0.58)$. In both breeds, cows in the milk group produced more milk throughout lactation than those in the content group $(+764 \mathrm{~kg}$ for Holstein cows and $+649 \mathrm{~kg}$ for Normande cows; $P<0.001)$. Over the first 14 wk of lactation, cows in the milk group had lower fat $(-2.1 \mathrm{~g} / \mathrm{kg}$ for Holstein cows and $-2.7 \mathrm{~g} / \mathrm{kg}$ for Normande cows; $P$ $<0.001)$ and protein content $(-1.5 \mathrm{~g} / \mathrm{kg}$ for Holstein cows and $-1.9 \mathrm{~g} / \mathrm{kg}$ for Normande cows in the high FS; $P<0.001 ;-1.2 \mathrm{~g} / \mathrm{kg}$ for Holstein cows and $-1.0 \mathrm{~g} /$ $\mathrm{kg}$ for Normande cows in the low FS; $P<0.01$ ) than those in the content group. In the high FS, cows in the milk group had a higher peak milk yield $(+4.2 \mathrm{~kg}$ for Holstein cows and $+3.2 \mathrm{~kg}$ for Normande cows; $P<$ $0.001)$, which was not the case in the low FS $(P=0.11$ for Holstein cows and $P=0.77$ for Normande cows). In both breeds, cows in the milk group had a higher lactation persistency $(+4$ percentage units; $P<0.05)$ than cows in the content group. In both breeds, cows had a similar BCS at calving between genetic groups $(P=0.13)$. Normande cows in the milk group had a lower BCS at nadir $(-0.25 ; P<0.01)$ and at the end of lactation $(-0.20 ; P<0.01)$ than in the content group. For Holstein cows, BCS was not affected by genetic groups $(P=0.99$ at nadir and $P=0.90$ at the end of lactation).

Effects of Restricted Nutrition. Cows in the high FS group produced more milk $(+2,495 \mathrm{~kg}$ for Holstein and $+1,481 \mathrm{~kg}$ for Normande cows; $P<0.001$ ) and more milk solids $(+168 \mathrm{~kg}$ for Holstein and $+109 \mathrm{~kg}$ for Normande cows; $P<0.001)$ throughout lactation than those in the low FS group. The effect of FS on total milk yield and milk solids yield was significantly more pronounced for Holstein than for Normande cows, but similar for both genetic groups within breeds. Over the first 14 wk of lactation, fat content was lower $(-0.5 \mathrm{~g} /$ $\mathrm{kg} ; P<0.05)$ and protein content was higher $(+2.0 \mathrm{~g} /$ $\mathrm{kg} ; P<0.001)$ for cows in the high than those in the low FS group. Cows in the high FS group had a higher 
ABILITY OF DAIRY COWS TO ENSURE PREGNANCY

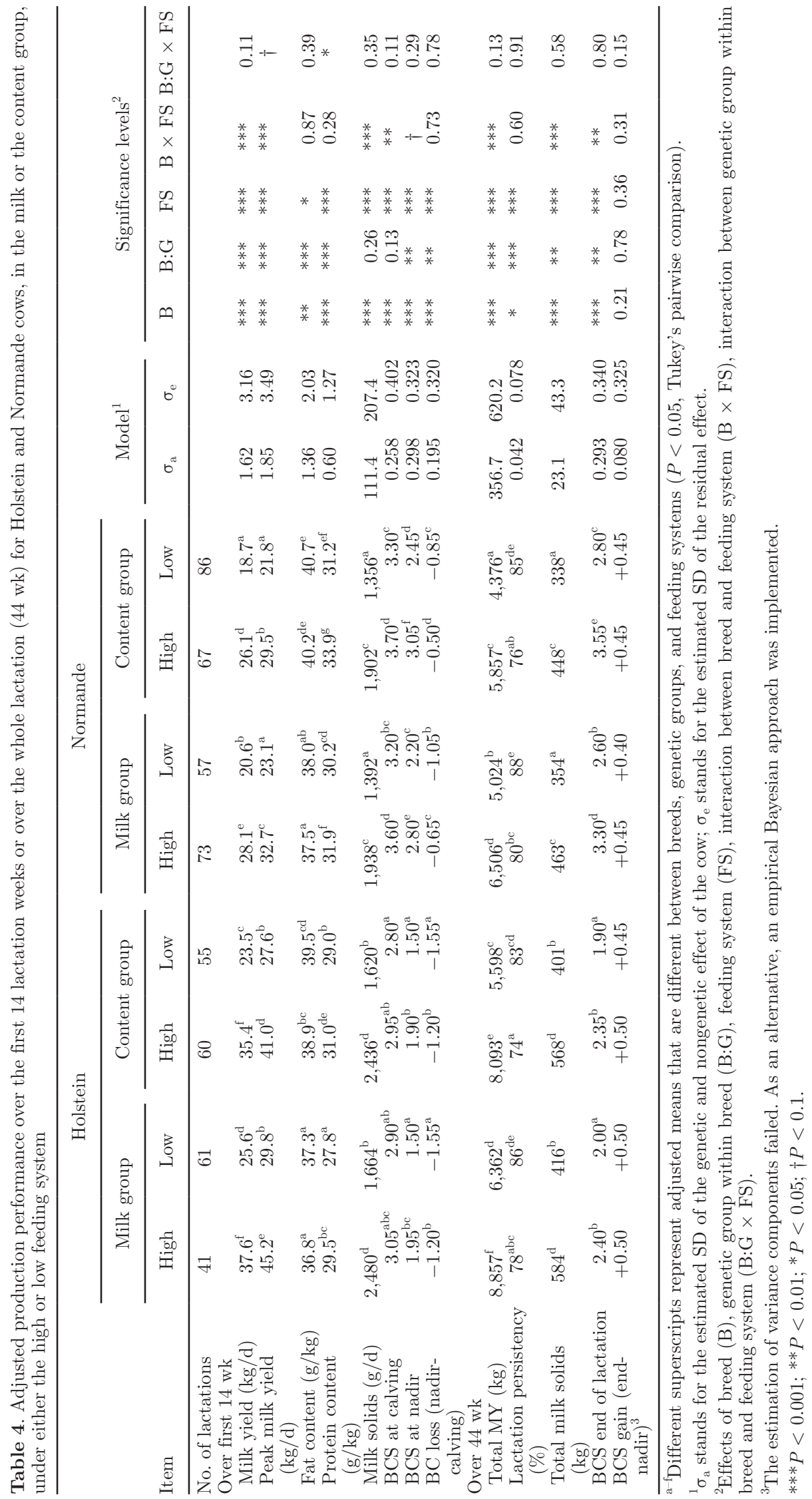


peak milk yield $(+14.4 \mathrm{~kg}$ for Holstein and $+8.6 \mathrm{~kg}$ for Normande cows; $P<0.001)$ and a lower lactation persistency ( -9 percentage units; $P<0.001$ ) than cows in the low FS group. Body condition score at calving was not affected by FS for Holstein cows $(P=0.53)$. Normande cows in the high FS group had higher BCS than those in the low FS group $(+0.40$ points; $P<$ 0.001). Cows in the high FS group had higher BCS at nadir $(+0.40$ points for Holstein and +0.60 points for Normande; $P<0.001)$ and higher BCS at the end of lactation $(+0.45$ points for Holstein and +0.70 points for Normande; $P<0.001$ ). Cows in the high FS group had a higher glycaemia $(+4.1 \mathrm{mg} / \mathrm{dL}$ at $20 \mathrm{~d}$ postpartum and $+3.7 \mathrm{mg} / \mathrm{dL}$ at $60 \mathrm{~d}$ postpartum; $P<0.001$ ) and uremia $(+4.3 \mathrm{mg} / \mathrm{dL}$ at $20 \mathrm{~d}$ postpartum and +5.7 $\mathrm{mg} / \mathrm{dL}$ at $60 \mathrm{~d}$ postpartum; $P<0.001)$ than those in the low FS group. Plasma concentration of fatty acids was not affected by FS at $20 \mathrm{~d}$ postpartum $(P=0.84)$; at $60 \mathrm{~d}$, cows in the high FS group had a lower plasma concentration of fatty acids than cows in the low FS group $(-25 \mu \mathrm{mol} / \mathrm{L} ; P<0.05)$.

\section{Lactation Performance During the Breeding Season}

First service was performed, on average, around $80 \mathrm{~d}$ postpartum and second service around $109 \mathrm{~d}$ postpartum. While being inseminated, cows were still producing large quantities of milk and milk solids and had already mobilized a substantial part of their body reserves (Table 6). Holstein cows produced more milk than Normande cows at first $(+9.1 \mathrm{~kg} / \mathrm{d}$ in the high FS and $+5.3 \mathrm{~kg} / \mathrm{d}$ in the low FS; $P<0.001)$ and second service $(+8.7 \mathrm{~kg} / \mathrm{d}$ in the high FS and $+5.2 \mathrm{~kg} / \mathrm{d}$ in the low FS; $P<0.001$ ); they also produced more milk solids at first $(+445 \mathrm{~g} / \mathrm{d}$ in the high FS and $+277 \mathrm{~g} / \mathrm{d}$ in the low FS; $P<0.001)$ and second service $(+391 \mathrm{~g} / \mathrm{d}$ in the high FS and $+194 \mathrm{~g} / \mathrm{d}$ in the low FS; $P<0.001$ ) than Normande cows. Holstein cows had a lower BCS at first $(-0.90$ points; $P<0.001)$ and second service $(-0.95$ points; $P<0.001)$ than Normande cows.

In both breeds, cows in the milk group produced more milk than those in the content group at first $(+2.1$ $\mathrm{kg} / \mathrm{d}$ for Holstein cows, $P<0.01$ and $+2.9 \mathrm{~kg} / \mathrm{d}$ for Normande cows; $P<0.001)$ and second service $(+3.1$ $\mathrm{kg} / \mathrm{d}$ for Holstein cows and $+2.3 \mathrm{~kg} / \mathrm{d}$ for Normande cows; $P<0.001)$. However, milk solids production at service was not affected by genetic group within breed (globally significant at first service, but Holstein cows in the milk group produced $+59 \mathrm{~g} / \mathrm{d}$ than those in the content group; $P=0.62$; Normande cows in the milk group produced $+52 \mathrm{~g} / \mathrm{d}$ than those in the content group; $P=0.64)$. For Holstein cows, BCS at first and second service was not affected by genetic groups $(P=$ 0.84 and $P=0.92$, respectively). Normande in the milk 
ABILITY OF DAIRY COWS TO ENSURE PREGNANCY

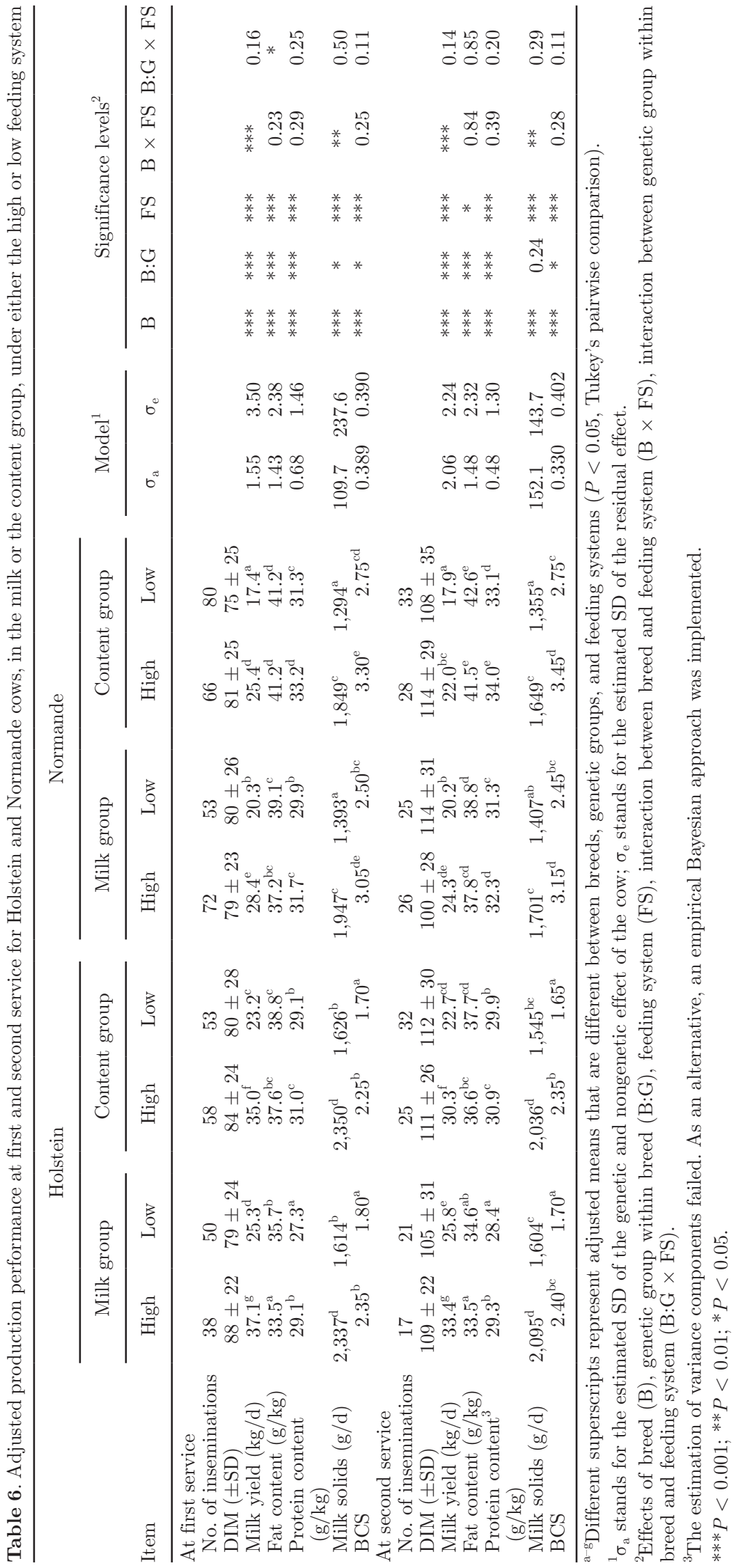


group had lower BCS at first $(-0.25 ; P<0.05)$ and at second service $(-0.30 ; P<0.05)$ than those in the content group.

\section{Fertility Performance}

Effects of Restricted Feeding on Likelihood of Conception. Over the 500 reproductive sequences (cow records in total) involved in the trials, 3 never resumed ovarian activity and 27 were never detected in estrus, which resulted in only 470 inseminated cows. Among those, DAIF ranged from 1 to $92 \mathrm{~d}$, with an average interval to conception of $30 \mathrm{~d}$. Seventy-four cows had censored DAIF, with an average censoring time of 74 d. A clear genetic by environment interaction was observed for DAIF (Table 7, Figure 1). For Normande cows, genetic group did not affect time to conception (Figure 1). Normande cows in the low FS group had a higher 42-d conception rate than in the high FS group (+6 percentage units), and overall conception rate was similar in both FS (about 87\%). However, Holstein cows in the high FS group were more likely to conceive than in the low FS group $(+11$ percentage units at $42 \mathrm{~d},+10$ percentage units at the end of the breeding season; Figure 1).

Holstein cows had a higher proportion of NF/EEM than Normande cows at first $(+7$ percentage units; $P<$ 0.10 ; Table 8$)$ and at combined first and second services $(+6$ percentage units, $P<0.10)$. In the low FS group, Holstein cows in the content group had more NF/EEM (+29 percentage units at first service and +26 percentage units at first and second services) than Holstein cows in the milk group. However, Holstein cows in the milk group under the high FS had an appreciable 53\% NF/EEM at first service. Estimated breeding values for milk yield was not associated with DAIF $(P=0.92)$. Higher protein content was associated with earlier DAIF (estimated effect: $\hat{\beta}=0.09$, HR $=1.1$ for $1 \mathrm{~g} / \mathrm{kg}, 95 \%$ CI $=1.0-1.2 ; P<0.01$ ). Each additional week from the start of the breeding season to first service was associated with lower chance of conception or later DAIF $(\hat{\beta}=-0.17, \mathrm{HR}=0.3$ per additional week, $95 \% \mathrm{CI}=0.2-0.5 ; P<0.001)$. Primiparous cows conceived earlier than multiparous cows $(\hat{\beta}=0.48$, $\mathrm{HR}=1.6,95 \% \mathrm{CI}=1.2-2.3 ; P<0.001)$. Cows without calving problems conceived earlier than cows with calving problems $(\hat{\beta}=0.40, \mathrm{HR}=1.5,95 \% \mathrm{CI}=1.0-2.3 ; P$ $<0.10)$.

Effects of Restricted Feeding on Embryo Mortality. Over the 470 cows inseminated during this trial, only 396 conceived. Among those, DAIC ranged from 1 to $92 \mathrm{~d}$, with an average interval to the insemination resulting in calving of $34 \mathrm{~d}$. Eighty-five cows had censored DAIC, with an average censoring time of $84 \mathrm{~d}$.
Holstein cows had a lower recalving rate than Normande cows $(-19$ percentage units; $P<0.001$; Table $8)$. Indeed, Normande cows were 1.6 times more likely to have a service leading to calving at a given time than Holstein cows $(P<0.10$; Table 7 , Figure 1$)$. Holstein cows had a lower proportion of service leading to calving $(-12$ percentage units at first service; $P<0.001$; -13 percentage units at second service; $P<0.10$ ) than Normande cows. Recalving rate was neither affected by genetic group $(P=0.32$; Table 8$)$ nor FS $(P=0.25)$. However, within breeds, the higher the EBV for milk yield, the higher the chances of service leading to calving $(P<0.10)$. At first service, we found a genetics by environment interaction on the proportion of calving services $(P<0.10$; Table 8$)$. The proportion of first service leading to calving was very low for Holstein cows in the content group under the low FS (24\%) and for Holstein cows in the milk group under the high FS (31\%). Recalving rate was the lowest for Holstein cows in the content group under the low FS (22\% at $42 \mathrm{~d}$ and $44 \%$ at the end of the breeding season; Figure 1, Table 8). In the high FS group, Holstein cows in the content group had a higher proportion of LEM than in the milk group (+10 percentage units at first and second services). Nevertheless, Normande cows in the content group also had more LEM than in the milk group at first service ( +9 percentage units). More days from the start of the breeding season to conception (DAIF) was associated with a lower chance of success and later DAIC $(\hat{\beta}=-0.25, \mathrm{HR}=0.3$ per additional week, $95 \%$ $\mathrm{CI}=0.1-0.3 ; P<0.001)$. Higher BCS at calving was associated with earlier DAIC $(\hat{\beta}=0.38, \mathrm{HR}=1.5$ for 1 point, $95 \% \mathrm{CI}=1.1-1.9 ; P<0.01)$.

\section{DISCUSSION}

To our knowledge, the association between milk yield and milk contents and fertility has never been studied before. We conjectured that, by having a lower peak milk yield and a lower lactose yield, cows with positive genetic merit for fat and protein content would have a higher energy status than those with positive genetic merit for milk yield and, thus, would preserve their reproductive performance while producing the same amount of milk solids.

\section{Merit for Fat and Protein Content Is Associated with Reduced Fertility in Holstein}

Fertility was globally impaired in our study compared with the goals of compact calving systems (e.g., 42-d pregnancy rate of $70 \%$ and final pregnancy rate of $90 \%$ in Ireland; Butler, 2014) and was particularly poor in Holstein cows. Holstein cows in the content group had 
ABILITY OF DAIRY COWS TO ENSURE PREGNANCY

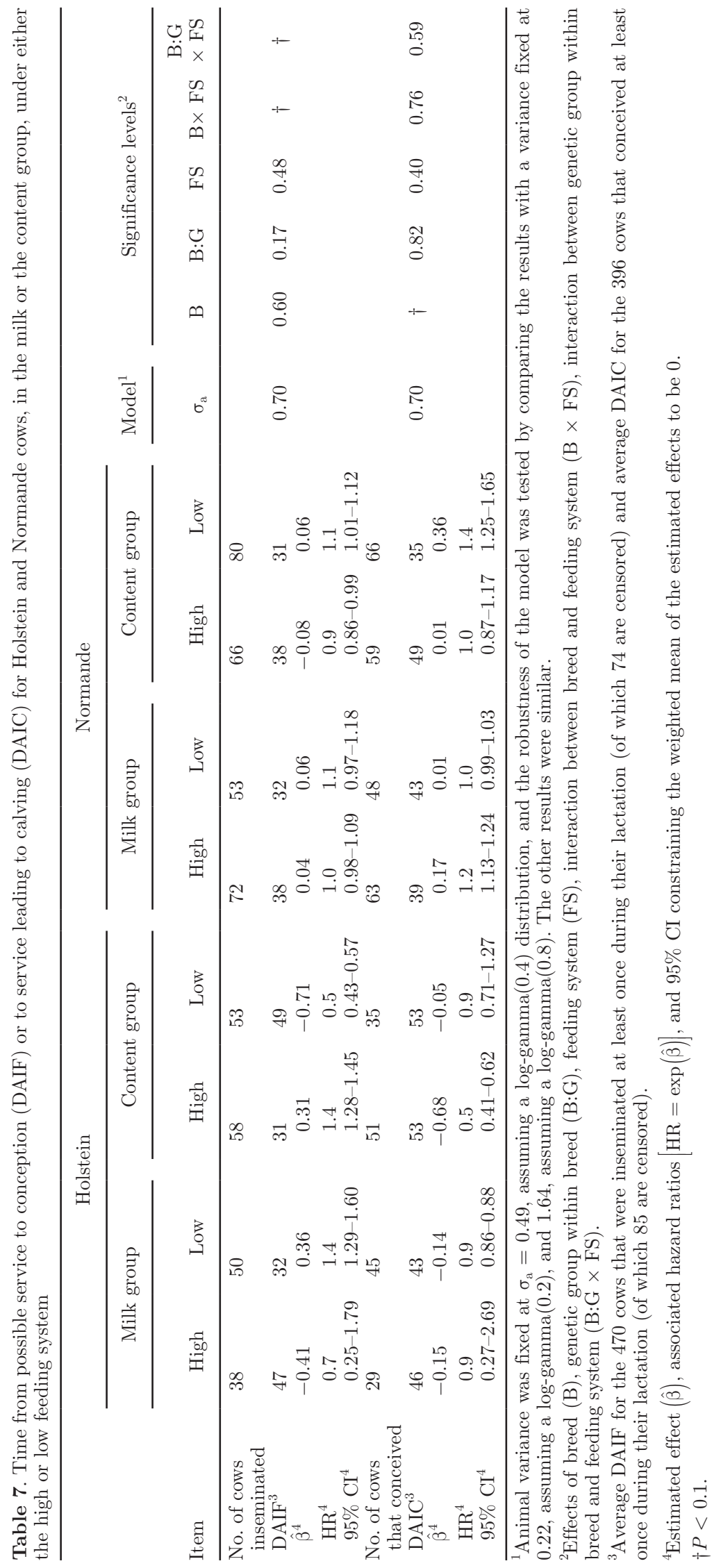


High FS
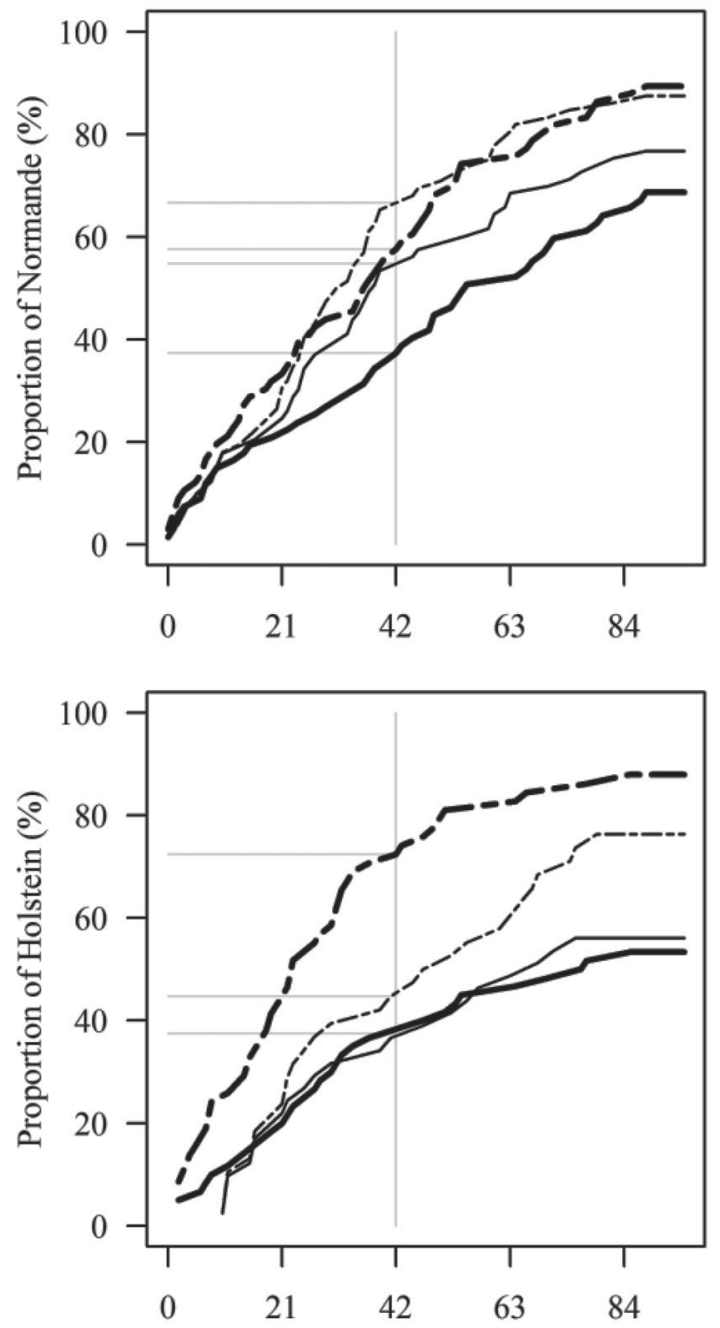

Days of the breeding season

\section{Low FS}
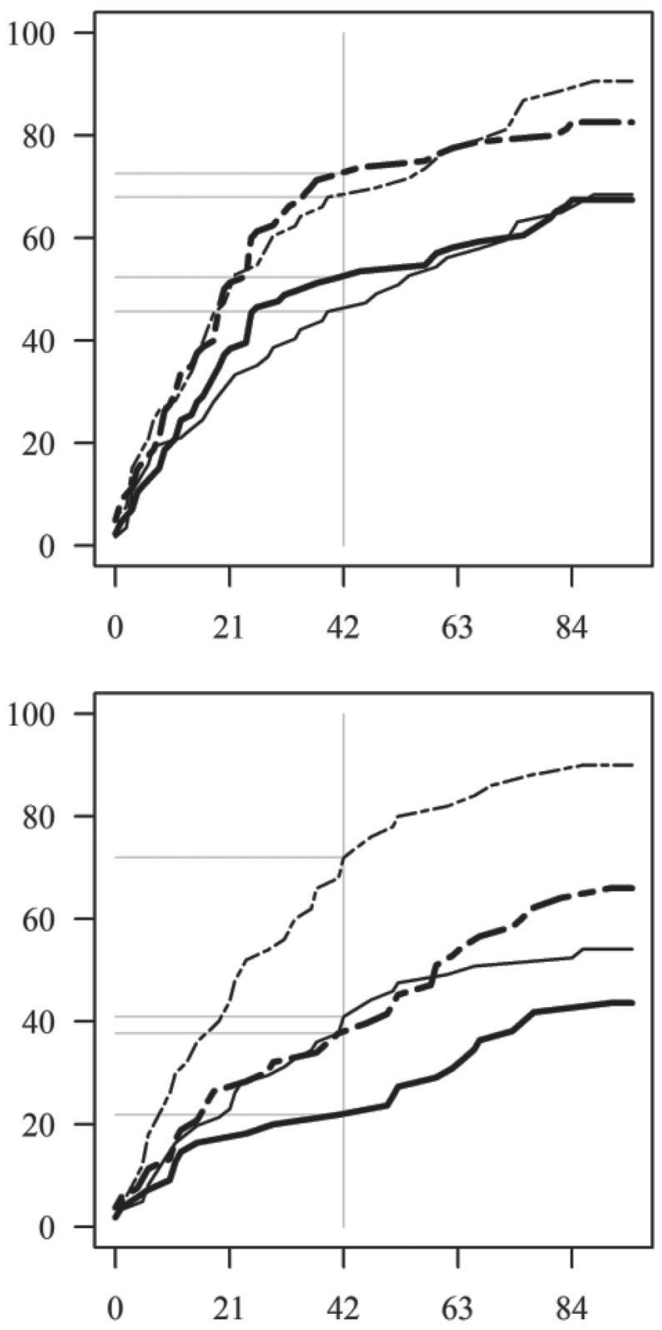

Days of the breeding season

Figure 1. Observed cumulative proportions of Normande (graphs on the top) and Holstein (graphs on the bottom) cows that conceived at service (dashed lines) and that had a service leading to calving (solid lines) from start of the breeding season to the end of the breeding season in the milk group $(\mathrm{n}=130$ Normande and 102 Holstein cows, thin lines) or in the content group ( $\mathrm{n}=153$ Normande and 115 Holstein cows, thick lines), under the high feeding system (FS; $\mathrm{n}=140$ Normande and 101 Holstein cows, graphs on the left) or low FS ( $\mathrm{n}=143$ Normande and 116 Holstein cows, graphs on the right).

the worst reproductive performance; however, the pattern of failure changed according to FS. Holstein cows in the content group and under the low FS showed the lowest conception rate $(38 \%$ at $42 \mathrm{~d}$ and $66 \%$ by the end of the breeding season). This is not consistent with their submission rate $(63 \%$ at 21 d; Bedere et al., $2016 \mathrm{~b}$ ), and the present study showed they had a higher proportion of NF/EEM than other groups (47\% at first and second services the range was from 19 to $29 \%$ for other groups). Holstein cows had the lowest BCS at calving, at nadir, at first and second service, and at the end of lactation. Low BCS at calving is known to be associated with low conception rate and longer days to conception (López-Gatius et al., 2003; Cardoso et al., 2013). In a previous study, we found that low BCS at nadir was associated with higher risk of NF/EEM (Cutullic et al., 2012). In the present study, higher protein content was associated with a higher chance for the cow to conceive, which is consistent with recent studies (Morton et al., 2016a,b). Holstein cows in the content group and under the low FS had a relatively low protein content $(28.9 \mathrm{~g} / \mathrm{kg}$ over the first $14 \mathrm{wk}$ of lactation) compared with their genetic merit for protein content. Protein content is known to be lower for 
ABILITY OF DAIRY COWS TO ENSURE PREGNANCY

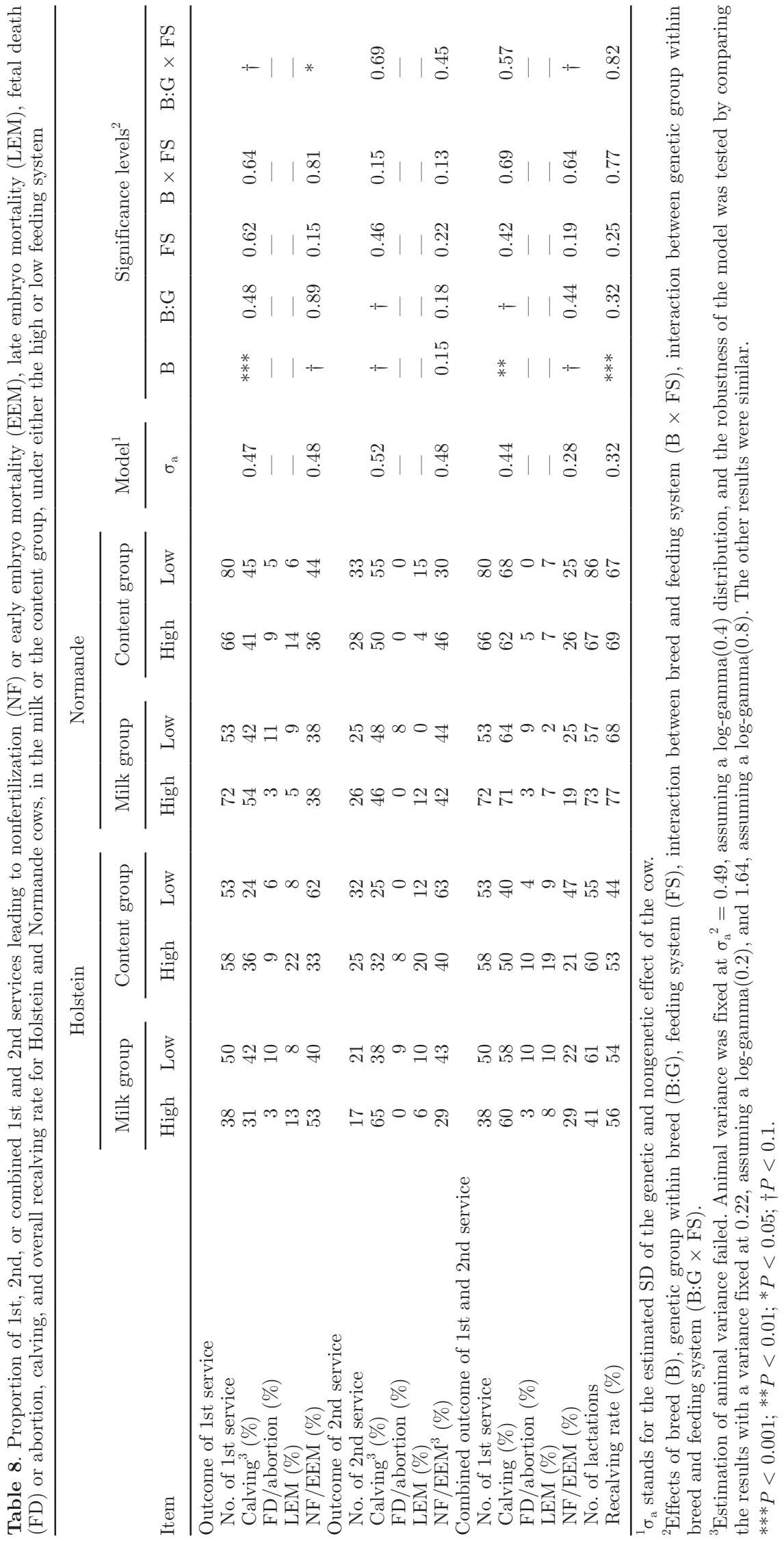


cows in severe and prolonged negative energy balance (Fulkerson et al., 2001). Negative energy balance is a complex condition that activates several endocrine signals (fall of IGF-I and leptin blood levels, increased insulin resistance, increased secretion of GH and catecholamine). These signals affect nutrient partitioning and are known to promote body reserve mobilization and milk production, and to even inhibit reproduction. Mobilization results in high plasma concentrations of fatty acids that are used as energy supply, but they also damage oocytes and endometrium, causing embryonic death (Santos et al., 2004; Friggens et al., 2010; Wathes et al., 2012). In our previous study, we showed that primiparous Holstein cows in the content group under the low FS had the lowest BW (Bedere et al., 2016a). According to their BCS, all Holstein cows suffered from a more severe and prolonged negative energy balance than Normande cows. This difference was even larger in the low FS group. When pregnancy was finally established for Holstein cows in the content group and under the low FS, $9 \%$ of first and second services led to LEM, which is within the range of most groups (from $2-10 \%)$. Nevertheless, due to their low proportion of first and second service that induced calving (40\%) and longer days to conception, Holstein cows in the content group and under the low FS had the lowest recalving rate $(22 \%$ at $42 \mathrm{~d}$ and $44 \%$ by the end of the breeding season). This result is below $50 \%$ and is underlying the limitations of such genetic characteristics in restrictive FS.

In the high FS group, Holstein cows in the milk group had the lowest conception rate $(45 \%$ at $42 \mathrm{~d}$ and $76 \%$ by the end of the breeding season); this is partly explained by more NF/EEM ( $53 \%$ of the services) and more LEM ( $13 \%$ at first service). Other results also showed that Holstein cows in the milk group had the lowest submission in both FS (Bedere et al., 2016b). Their ability to be pregnant at second service balanced this result so that their recalving rate $(56 \%)$ is not different from Holstein cows in the milk group under the low FS (54\%) and Holstein cows in the content group under high FS (53\%). However, in our study, Holstein cows in the content group under the high FS had a high proportion of LEM (19\% at first and second services). Late embryo mortality are known to be associated with lower lactation persistency (Buckley et al., 2003; Cutullic et al., 2012). Consistently, Holstein cows in the content group under the high FS had the lowest lactation persistency $(74 \%)$, and this phenomenon was also observed in Normande cows in the content group under the high FS (persistency of $76 \%$ ). In the present study, persistency was estimated through the ratio between milk yields from 100 to $200 \mathrm{~d}$ over 0 to $100 \mathrm{~d}$. A limit of such an indicator is that the effect of persistency may be confounded with the effect of peak milk yield. Other measurements of persistency exist [e.g., parameters of the Wilmink (1987) curve], but they could not be estimated in the present study because of the occurrence of atypical lactation profiles (peak milk yield occurring during the last 2 third of lactation, more than one peak milk yield, and so on). In our experiment, Holstein cows produced an extra $10 \mathrm{~kg}$ of milk daily at peak for the first and second services than Normande cows, suggesting that low persistency may not impair embryo survival below a certain milk yield threshold. This is consistent with the fact that LEM are more frequent in high producing cows (Grimard et al., 2006). It is also known that cows with high genetic merit for milk production have low genetic merit for BCS (genetic correlation about -0.37 , heritability of BCS ranging from 0.20 to 0.50; Bastin and Gengler, 2013). Our result shows that higher BCS at calving was associated with higher chances of service resulting in successful recalving; this is also consistent with the fact that BCS is positively associated with probability of pregnancy (Buckley et al., 2003; Santos et al., 2009) and negatively associated with LEM (Silke et al., 2002; Grimard et al., 2006). This association is partly consistent with the positive genetic correlation between BCS and 42-d recalving rate (0.43; Pryce and Harris, 2006). Morton et al. (2016a,b) showed that higher protein content was associated with higher fertility status. Interestingly, those authors reported that if protein content is low (i.e., below $30 \mathrm{~g} / \mathrm{kg}$ ), cows with high milk yield are more likely to be inseminated, to conceive, and to be pregnant than those with lower milk yield (i.e., 5,000 vs. 2,000 kg of milk over $120 \mathrm{DIM})$. This suggests that the association between protein content and reproduction may also be related to other causes than the extent of negative energy balance. Further studies are required to better understand the underlying biological mechanisms. Some of our results suggest a possible link between genetic characteristics of milk fat and protein contents and fertility. Indeed, we found that cows in the content group perform worst in both FS and breeds (lower conception and pregnancy rates). This is in agreement with EBV for milk yield associated with a higher chance to have a successful insemination (in this analysis, the effect of genetic group was not significant and therefore not included in the model). Other studies observed results similar to ours, with chances of pregnancy positively related to high milk yield (Gröhn and Rajala-Schultz, 2000; Buckley et al., 2003). These findings are intriguing, given the consensus that the higher the milk yield (phenotypically and genetically), the worse the reproductive performance (Royal et al., 2000; Friggens et al., 2010; Walsh et al., 2011). However, they are consistent with the large variability in the direction 
of relationship between milk yield and fertility at the individual level. Indeed, Nebel and McGilliard (1993) and Bello et al. (2013) found that herds with high genetic merit for milk yield had poor fertility status, which was not observed between cows within herds. Our results show that, in both breeds, cows in the milk group have delayed cyclicity compared with the content group (Bedere et al., 2016a). Further studies are needed to confirm whether cows in the content group have impaired fertility because selecting for fat content may have impaired embryo survival or not. This predisposition could explain the high proportion of LEM for Holstein cows in the content group under the high FS. This hypothesis, combined with the effects of severe negative energy balance (leading to a poor ability of oocytes to develop themselves), could explain NF/EEM of the Holstein in the content group under the low FS. Unfortunately, genetic merit for fertility traits of the animals involved in our study was not available, which could be another underlying explanation of some of our results. Further investigation on genetic merit for fertility and its association with genetic merit for production traits (yields and contents) is needed.

\section{Normande Ability to be Pregnant is Preserved by Adaptive Response}

As expected, Normande cows under nutritive restriction produced less milk and limited their body reserves mobilization, whereas Holstein cows limited milk production reduction and mobilized a larger part of their body reserves (Dillon et al., 2003a; Walsh et al., 2008; Delaby et al., 2009). Consistent with the literature (Dillon et al., 2003b; Michel et al., 2003; Walsh et al., 2008), we found that Normande cows had a higher recalving rate thanks to more fertilizations and less pregnancy losses than Holstein cows under both contrasted FS. Results from previous studies also showed that, in both FS, Normande had an earlier resumption of ovarian cyclicity, more normal cyclicity patterns, more ovulations due to shorter cycles, regular ovulation detection rate (about 70\%), and higher submission rate (Cutullic et al., 2009, 2011; Bedere et al., 2016a,b). The current study also proved that fertility performance of dairy cows exhibits a genetic by environment interaction. We found no significant effect of genetic group and FS on fertility of Normande, but Normande cows in the low FS group conceived earlier than those in the high FS group. Our previous studies showed that this difference is notable for submission rate and was related to a higher estrus expression (Cutullic et al., 2011). Normande cows in the milk group under the high FS had the best recalving rate $(77 \%)$ compared with other groups; they calved at 3.60 points of BCS (0-5 scale), mobilized few body reserves, had a low peak milk yield $(32.7 \mathrm{~kg})$, and a high lactation persistency (80\%). Overall, they produced an appreciable $6,498 \mathrm{~kg}$ of milk and $460 \mathrm{~kg}$ of milk solids. Consensus exists in the literature about the fact that these levels of production performance are ideal regarding reproduction success in compact calving systems (López-Gatius et al., 2003; Roche et al., 2009; Friggens et al., 2010). Benefits of breeding such cows should be investigated further. Feeding system had no effect on recalving rate, which is consistent with other studies (Kennedy et al., 2003; Horan et al., 2004; Vance et al., 2013). This suggests that the adaptive strategy of the animals in case of nutrient restriction (support milk yield vs. preserve body condition) affects more dairy cows' ability to be pregnant than the nutritive uptake. A complementary study was performed on our data from 2006 to 2013 by Cloet et al. (2015), using the approach developed by Ollion et al. (2016). That study identified 5 trade-off scenarios based on production, mobilization, and reproduction performance of the cows. These scenarios helped us to confirm dairy cows' adaptive strategies to nutrient supply: under high nutrients supply, Holstein cows invest their energy in milk yield whereas Normande cows invest in body reserves, and, under restricted nutrients supply, Holstein cows mobilize their body reserves to support milk production whereas Normande cows limit both mobilization and production. Further investigations on adaptive strategies of dairy cows to nutrient supply and their implication for robustness are needed.

\section{CONCLUSIONS}

This study confirmed that Normande cows have a superior ability to ensure pregnancy than Holstein cows. A genetic by environment interaction exists on fertility performance. At identical genetic merit for milk solids production, Normande cows with high genetic merit for milk yield, and Normande cows with high genetic merit for fat and protein content have similar fertility. However, Holstein cows with high genetic merit for fat and protein content had lower fertility compared with Holstein cows with high genetic merit for milk yield. Under the restricted feeding system they had a high NF/EEM rate, whereas under the higher feeding system they had a high proportion of pregnancy losses. We concluded that selecting dairy cows with more emphasis on fat and protein content instead of milk yield may decrease the ability of dairy cows to ensure pregnancy. Further research on genetic merit for fertility and its association with genetic merit for production traits (yields and contents) is needed. 


\section{ACKNOWLEDGMENTS}

The research leading to these results received funding from the European Union Seventh Framework Programs (FP7:2007-2013) under the grant agreement n³11776 (PROLIFIC: Pluridisciplinary study for a RObust and sustainabLe Improvement of Fertility In Cows, INRA, Paris, France). The study was also funded by the Brittany Region, France. We thank the staff of the experimental farm of Le Pin-au-Haras (Normandy, France) or their help in managing the herd and collecting the samples and data. We are also grateful to the laboratory staff of INRA and Agrocampus Ouest for analyzing all the samples collected. The pertinent comments and advice of the two anonymous referees are also gratefully acknowledged.

\section{REFERENCES}

Bastin, C., and N. Gengler. 2013. Genetics of body condition score as an indicator of dairy cattle fertility. A review. Biotechnol. Agron. Soc. Environ. 17:64-75.

Bazin, S., P. Augeard, M. Carteau, H. Champion, Y. Chilliard, G. Cuylle, C. Disenhaus, G. Durand, R. Espinasse, A. Gascoin, M. Godineau, D. Jouanne, O. Ollivier, and B. Remond. 1984. Grille de notation de l'état d'engraissement des vaches pie-noires. In RNED bovin. Paris, France.

Bedere, N., L. Delaby, V. Ducrocq, S. Leurent-Colette, and C. Disenhaus. 2016a. Toward improved postpartum cyclicity of primiparous dairy cows: Effects of genetic merit for production traits under contrasting feeding systems. J. Dairy Sci. 99:1266-1276. https:// doi.org/10.3168/jds.2015-9843.

Bedere, N., C. Disenhaus, V. Ducrocq, S. Leurent-Colette, and L. Delaby. 2016b. Ability of dairy cows to be inseminated according to breed and genetic merit for production traits under contrasting pasture based feeding systems. Animal https://doi.org/10.1017/ S1751731116002111.

Bello, N. M., J. P. Steibel, R. J. Erskine, and R. J. Tempelman. 2013. Cows and herds constitute distinct hierarchical levels of heterogeneity in the variability of and association between milk yield and pregnancy outcome in dairy cows. J. Dairy Sci. 96:2314-2326. https://doi.org/10.3168/jds.2012-6264.

Buckley, F., K. O'Sullivan, J. F. Mee, R. D. Evans, and P. Dillon. 2003. Relationships among milk yield, body condition, cow weight, and reproduction in spring-calved Holstein-Friesians. J. Dairy Sci. 86:2308-2319. https://doi.org/10.3168/jds.S0022-0302(03)738235.

Butler, S. T. 2014. Nutritional management to optimize fertility of dairy cows in pasture-based systems. Animal 8:15-26. https://doi. org/10.1017/S1751731114000834.

Cardoso, F. C., S. J. LeBlanc, M. R. Murphy, and J. K. Drackley. 2013. Prepartum nutritional strategy affects reproductive performance in dairy cows. J. Dairy Sci. 96:5859-5871. https://doi. org/10.3168/jds.2013-6759.

Cloet, E., L. Delaby, E. Ollion, and F. Blanc. 2015. La robustesse des vaches laitières: Une approche basée sur les compromis entre fonctions biologiques et perspectives de valorisation dans les schémas de sélection génétique. ISA, Lille, France.

Cutullic, E., L. Delaby, D. Causeur, G. Michel, and C. Disenhaus. 2009. Hierarchy of factors affecting behavioural signs used for oestrus detection of Holstein and Normande dairy cows in a seasonal calving system. Anim. Reprod. Sci. 113:22-37. https://doi. org/10.1016/j.anireprosci.2008.07.001.

Cutullic, E., L. Delaby, Y. Gallard, and C. Disenhaus. 2011. Dairy cows' reproductive response to feeding level differs according to the reproductive stage and the breed. Animal 5:731-740. https:// doi.org/10.1017/S1751731110002235.

Cutullic, E., L. Delaby, Y. Gallard, and C. Disenhaus. 2012. Towards a better understanding of the respective effects of milk yield and body condition dynamics on reproduction in Holstein dairy cows. Animal 6:476-487. https://doi.org/10.1017/S175173111100173X.

Delaby, L., P. Faverdin, G. Michel, C. Disenhaus, and J. L. Peyraud 2009. Effect of different feeding strategies on lactation performance of Holstein and Normande dairy cows. Animal 3:891-905. https://doi.org/10.1017/S1751731109004212.

Dillon, P., F. Buckley, P. O'Connor, D. Hegarty, and M. Rath. 2003a. A comparison of different dairy cow breeds on a seasonal grassbased system of milk production 1. Milk production, live weight, body condition score and DM intake. Livest. Prod. Sci. 83:21-33. https://doi.org/10.1016/S0301-6226(03)00041-1.

Dillon, P., S. Snijders, F. Buckley, B. Harris, P. O'Connor, and J. F. Mee. 2003b. A comparison of different dairy cow breeds on a seasonal grass-based system of milk production 2. Reproduction and survival. Livest. Prod. Sci. 83:35-42. https://doi.org/10.1016/ S0301-6226(03)00042-3.

Friggens, N. C., C. Disenhaus, and H. V. Petit. 2010. Nutritional subfertility in the dairy cow: Towards improved reproductive management through a better biological understanding. Animal 4:11971213. https://doi.org/10.1017/S1751731109991601.

Fulkerson, W., J. Wilkins, R. C. Dobos, G. M. Hough, M. E. Goddard, and T. Davison. 2001. Reproductive performance in Holstein-Friesian cows in relation to genetic merit and level of feeding when grazing pasture. Anim. Sci. 73:397-406.

Gautam, G., T. Nakao, K. Yamada, and C. Yoshida. 2010. Defining delayed resumption of ovarian activity postpartum and its impact on subsequent reproductive performance in Holstein cows. Theriogenology 73:180-189. https://doi.org/10.1016/j. theriogenology.2009.08.011.

Grimard, B., S. Freret, A. Chevallier, A. Pinto, C. Ponsart, and P. Humblot. 2006. Genetic and environmental factors influencing first service conception rate and late embryonic/foetal mortality in low fertility dairy herds. Anim. Reprod. Sci. 91:31-44. https://doi. org/10.1016/j.anireprosci.2005.03.003.

Gröhn, Y. T., and P. J. Rajala-Schultz. 2000. Epidemiology of reproductive performance in dairy cows. Anim. Reprod. Sci. 60-61:605614. https://doi.org/10.1016/S0378-4320(00)00085-3.

Horan, B., J. F. Mee, M. Rath, P. O'Connor, and P. Dillon. 2004. The effect of strain of Holstein-Friesian cow and feeding system on reproductive performance in seasonal-calving milk production systems. Anim. Sci. 79:453-467.

Humblot, P. 2001. Use of pregnancy specific proteins and progesterone assays to monitor pregnancy and determine the timing, frequencies and sources of embryonic mortality in ruminants. Theriogenology 56:1417-1433. https://doi.org/10.1016/S0093-691X(01)00644-6.

Kennedy, J., P. Dillon, K. O'Sullivan, F. Buckley, and M. Rath. 2003. The effect of genetic merit for milk production and concentrate feeding level on the reproductive performance of Holstein-Friesian cows in a grass-based system. Anim. Sci. 76:297-308.

Kerbrat, S., and C. Disenhaus. 2004. A proposition for an updated behavioural characterisation of the oestrus period in dairy cows Appl. Anim. Behav. Sci. 87:223-238. https://doi.org/10.1016/j. applanim.2003.12.001

López-Gatius, F., J. Yániz, and D. Madriles-Helm. 2003. Effects of body condition score and score change on the reproductive performance of dairy cows: a meta-analysis. Theriogenology 59:801-812.

Mészáros, G., J. Sölkner, and V. Ducrocq. 2013. The survival kit: Software to analyze survival data including possibly correlated random effects. Comput. Methods Programs Biomed. 110:503-510. https://doi.org/10.1016/j.cmpb.2013.01.010.

Michel, A., C. Ponsart, S. Freret, and P. Humblot. 2003. Influence de la conduite de la reproduction sur les résultats à l'insémination en période de pâturage. Pages 131-134 in Rencontres Recherches Ruminants. Paris, France. INRA-Institut de l'Elevage, Paris, France.

Morton, J. M., M. J. Auldist, M. L. Douglas, and K. L. Macmillan. 2016a. Associations between milk protein concentration, milk 
yield, and reproductive performance in dairy cows. J. Dairy Sci. 99:10033-10043. https://doi.org/10.3168/jds.2016-11275.

Morton, J. M., M. J. Auldist, M. L. Douglas, and K. L. Macmillan. 2016b. Associations between milk protein concentration at various stages of lactation and reproductive performance in dairy cows. J. Dairy Sci. 99:10044-10056. https://doi.org/10.3168/jds.201611276.

Nebel, R. L., and M. L. McGilliard. 1993. Interactions of high milk yield and reproductive performance in dairy cows. J. Dairy Sci. 76:3257-3268. https://doi.org/10.3168/jds.S0022-0302(93)776626.

Ollion, E., S. Ingrand, L. Delaby, J. M. Trommenschlager, S. ColetteLeurent, and F. Blanc. 2016. Assessing the diversity of trade-offs between life functions in early lactation dairy cows. Livest. Sci. 183:98-107. https://doi.org/10.1016/j.livsci.2015.11.016.

Petersson, K.-J., E. Strandberg, H. Gustafsson, and B. Berglund. 2006. Environmental effects on progesterone profile measures of dairy cow fertility. Anim. Reprod. Sci. 91:201-214. https://doi. org/10.1016/j.anireprosci.2005.04.010.

Pollott, G. E., and M. P. Coffey. 2008. The effect of genetic merit and production system on dairy cow fertility, measured using progesterone profiles and on-farm recording. J. Dairy Sci. 91:3649-3660. https://doi.org/10.3168/jds.2007-0913.

Pryce, J. E., and B. L. Harris. 2006. Genetics of body condition score in New Zealand dairy cows. J. Dairy Sci. 89:4424-4432. https:// doi.org/10.3168/jds.S0022-0302(06)72490-0.

R Core Team. 2016. R: A Language and Environment for Statistical Computing. R Development Core Team, Vienna, Austria.

Roche, J. R., N. C. Friggens, J. K. Kay, M. W. Fisher, K. J. Stafford, and D. P. Berry. 2009. Invited review: Body condition score and its association with dairy cow productivity, health, and welfare. J. Dairy Sci. 92:5769-5801. https://doi.org/10.3168/jds.2009-2431.

Royal, M., G. E. Mann, and A. P. Flint. 2000. Strategies for reversing the trend towards subfertility in dairy cattle. Vet. J. 160:53-60. https://doi.org/10.1053/tvjl.1999.0450.
Santos, J. E. P., H. M. Rutigliano, and M. F. S. Filho. 2009. Risk factors for resumption of postpartum estrous cycles and embryonic survival in lactating dairy cows. Anim. Reprod. Sci. 110:207-221. https://doi.org/10.1016/j.anireprosci.2008.01.014.

Santos, J. E. P., W. W. Thatcher, R. C. Chebel, R. L. A. Cerri, and K. N. Galvão. 2004. The effect of embryonic death rates in cattle on the efficacy of estrus synchronization programs. Anim. Reprod. Sci. 82-83:513-535. https://doi.org/10.1016/j.anireprosci.2004.04.015.

Silke, V., M. G. Diskin, D. A. Kenny, M. P. Boland, P. Dillon, J. F. Mee, and J. M. Sreenan. 2002. Extent, pattern and factors associated with late embryonic loss in dairy cows. Anim. Reprod. Sci. 71:1-12. https://doi.org/10.1016/S0378-4320(02)00016-7.

Vance, E. R. C. P. Ferris, C. T. Elliott, H. M. Hartley, and D. J. Kilpatrick. 2013. Comparison of the performance of Holstein-Friesian and Jersey $\times$ Holstein-Friesian crossbred dairy cows within three contrasting grassland-based systems of milk production. Livest. Sci. 151:66-79. https://doi.org/10.1016/j.livsci.2012.10.011.

Walsh, S., F. Buckley, K. Pierce, N. Byrne, J. Patton, and P. Dillon. 2008. Effects of breed and feeding system on milk production, body weight, body condition score, reproductive performance, and postpartum ovarian function. J. Dairy Sci. 91:4401-4413. https:// doi.org/10.3168/jds.2007-0818.

Walsh, S. W.. E. J. Williams, and A. C. O. Evans. 2011. A review of the causes of poor fertility in high milk producing dairy cows. Anim. Reprod. Sci. 123:127-138. https://doi.org/10.1016/j. anireprosci.2010.12.001.

Wathes, D. C., A. M. Clempson, and G. E. Pollott. 2012. Associations between lipid metabolism and fertility in the dairy cow. Reprod. Fertil. Dev. 25:48-61. https://doi.org/10.1071/RD12272.

Wilmink, J. B. M. 1987. Adjustment of test-day milk, fat and protein yield for age, season and stage of lactation. Livest. Prod. Sci. 16:335-348. https://doi.org/10.1016/0301-6226(87)90003-0. 